\title{
Students' educational level and their goal choices, self-efficacy, motivation, and writing performance
}

Hosseini Fatemi, Azar

Ferdowsi University of Mashhad, Iran (hfatemi@ferdowsi.um.ac.ir)

Vahidnia, Fatemeh $\bowtie$

Ferdowsi University of Mashhad, Iran (Fateme.vahidnia@yahoo.com)

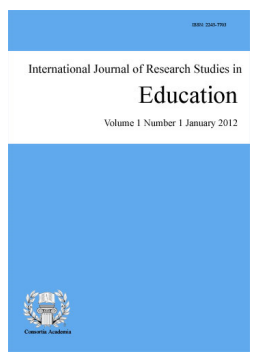

ISSN: $2243-7703$ Online ISSN: 2243-7711

\begin{abstract}
This study sought to survey the potential effect of Iranian EFL learners' educational level on their motivation, self-efficacy, choice of goals, and writing achievement. To conduct such a research, a group of 93 university students $(\mathrm{MA}=38, \mathrm{BA}=55)$ took part. The study was implemented in two levels. At level one, students' goal choice was surveyed by presenting them three levels (A, B, and C) as their goals for writing in which they had the choice to select one of these levels as their choice and model. The second level was based on three questionnaires gathered from the same students prior to writing examination. The findings of the study revealed that MA learners exhibited higher level of English and General self-efficacy and motivation. In addition, MAs surpassed BAs in writing scores and selected the most challenging goal as compared to BAs who preferred to pick the easy goal.
\end{abstract}

Keywords: writing performance; self-efficacy; goal choice; motivation; EFL learners 


\section{Students' educational level and their goal choices, self-efficacy, motivation, and writing performance}

\section{Introduction}

There has been growing concern with the students' developmental period which has a role in their current and future academic success and their changes in cognitive and affective processes that direct and maintain their action. Based on the modern views of cognitive development, a person's developmental level and experiences bring about variation in the production of knowledge (Meece, 1997; Siegler, 1991, in Schunk \& Pajares, 2002). Thus, there should be something unique in developmental period that put individuals in sudden or gradual changes.

In similar fashion, pedagogy places great emphasis on existing motivation theories such as operation of goals and efficacy beliefs (Schunk \& Pajares, 2002). Self-efficacy is in focus for more than two decades due to being as a crucial motivational construct in the study of human behavior (Bandura \& Locke, 2003). In a quite similar way, there is ample evidence indicating that the operation of goals proceeds to be a fundamental and dominant topic in motivation (Bandura, 1986; Locke, Frederick, Lee, \& Bobko, 1984; Locke, Motowidlo, \& Bobko, 1986).

Given the scant research available so far, there exists obviously a need for further research in this domain particularly within an EFL context. This is mainly true apropos to the topic of educational level; the efficacy beliefs and motivation literature thus far suggested that self-efficacy and motivation not only deal with academic achievement but also with age and/or educational level (e.g., Pajares \& Schunk, 2001). However, it is somehow unknown if this is also true corresponding to learners' goal choice and writing achievement. It is the objective of the present investigation to fill these gaps in the literature.

\section{Literature Review}

\subsection{Self-efficacy}

According to Bandura, self-efficacy is "beliefs in one's capability to organize and execute the courses of action required to manage prospective situations and to produce given attainments" (1986, p. 392). In 1986, Bandura asserted that, "Many students have difficulty in school not because they are incapable of performing successfully, but because they are incapable of believing that they can perform successfully" (p. 390). As stated by socio-cognitive theory, efficacy beliefs coupled with goal systems are able to strengthen motivation and performance through increasing effort or persistence (Bandura, 2001) and higher level of self-efficacy equates with embarking on higher levels of goals over time (Locke \& Latham, 1990).

\subsection{Developmental stages of self-efficacy}

Self-efficacy progresses in stages when an individual moves on through life's various phases. The starting point of self-efficacy development is within the student's family environment and its progress continues with age because of being exposed to models and the sense of progress which derives from mastery experiences. Self-efficacy experiences got from family and social comparison have a leading role in individuals' self-efficacy development. Peers also exert vulnerable effect on the individuals' efficacy beliefs (Bandura, 1986).

In case of reassessing their competence, children's self-perceptions may shift while going through a developmental process (Marsh, Craven, \& Debus, 1999, cited inYeung, Lau, \& Nie, 2011). Young children usually overestimate their efficacy beliefs and capability, but their beliefs increase in accuracy with children age 
(Paris \& Oka, 1986; Stipek, 1993). Bandura (1986) has claimed that the improvement in actual cognitive and behavioral skills is directly accompanied with the development of higher self-efficacy and; thus, it can be inferred that as long as these skills develop, so will self-efficacy.

Inadequate body of knowledge exists about the development of beliefs for writing and about the possible interaction of achievement-level differences with developmental differences in the higher grades. There are also a small number of studies which surveyed the self-efficacy beliefs of children about writing (e.g., Schunk \& Swartz, 1993). Consequently, there is lack of research which has thoroughly and scientifically delved into the developmental or achievement- level differences in children's beliefs about writing to date. According to the survey of some studies, the beliefs of adult and skilled participants are less strongly associated with achievement for writing (McCarthy et al., 1985; Shell et al., 1989); however, how this difference in the strength of the relation for writing develops and whether this difference also occurs for persons at other achievement levels presently are not known.

\subsection{Motivation}

We always resort to motivation as we gather to pursue common goals. Almost all people agree that motivation is essential, however abundant different theories exist. In a similar vein, educational psychologists have long recognized the significance of motivation for supporting students' learning. Dörnyei and Ottó (1998) defined motivation as "the dynamically changing cumulative arousal in a person that initiates, directs, coordinates, amplifies, terminates, and evaluates the cognitive processes" (p. 64).

Development of motivation - It has shown by copious of studies that students' adaptive motivation is likely to lesson as they grow up. A large number of investigators have proposed that students' motivation gradually weaken over time, particularly during adolescence (Broussard \& Garrison, 2004; Guthrie et al., 2000; Murphy \& Alexander, 2000; Watt, 2008; Yeung, Lau, \& Nie, 2011; Yeung \& McInerney, 2005). As a case in point, it is maintained that many students go through "a deterioration in perceptions of self, affect, motivation, and performance during early adolescence and in particular, when they moved to middle-level schools" (Midgley \& Edelin, 1998, p. 195, cited in Yeung, Lau, \& Nie, 2011). In 2005, Yeung and McInerney have also indicated that through high school years, deterioration occurs in various motivational constructs. In a related line of investigation, it was revealed that students' intrinsic motivation for learning lessens generally with age (Harter, 1981; Lepper, Sethi, Dialdin, \& Drake, 1997; Sakurai \& Takano, 1985, cited in Carreira, 2006).

A range of possible reasons may be at work to bring about such a descending developmental pattern. One of the reasons may be related to this fact that students may begin to cast doubt on the significance of education and devoting their effort in school activities as they mature (Wigfield \& Eccles, 2000, cited inYeung, Lau, \& Nie, 2011). Along with the decline in students' perceived significance of education, not finding the relevance of school activities to their future can result in their reduced level of interest and mastery orientation. To be exact, students have less tendency to devote their time and effort in learning tasks and school activities and are willing to have lower mastery goal orientation while growing up (e.g., Bouffard, Marcoux, Vezeau, \& Bordeleau, 2003; Gottfried, Fleming, \& Gottfried, 2001; Lepper et al., 2005; Meece \& Miller, 2001; Spinath \& Spinath, 2005, cited inYeung, Lau, \& Nie, 2011).

A number of investigators (e.g., Bouffard, Vezeau, \& Bordeleau, 1998, cited in Yeung, Lau, \& Nie, 2011) maintain that the interpretation of the learning context can shed light on the students' progress in motivation. Moreover, a change in the environment of learning throughout adolescence can lead to a change in the developmental trend. Due to the less supportive classroom environment, Feldlaufer, Midgley, and Eccles (1988) argued that decrease in motivation may be seen in the transition from primary to middle school (cited in Yeung, Lau, \& Nie, 2011).

To date, significant associations between classroom environments and students' motivation in learning were demonstrated by several researches. In 2009, Lee, Yin, and Zhang attested that there was a positive association 
between students' intrinsic motivation and a positive classroom environment with great teacher support. There is evidence which has indicated that teachers' behaviors affected students' motivation (e.g., den Brok, Levy, Brekelmans, \& Wubbels, 2005). In a similar vein, Noels (2001) stated that "the more students perceived their teachers as controlling and as failing to provide instructive feedback, the less they were intrinsically motivated" (cited in Dornyei, 2005, p. 77). To boot, it has exhibited that variation in the physical circumstance of school could bring about a change in motivation and behaviors of students in school (McEwan, Edgerton, \& McKechnie, 2010).

\subsection{Writing}

As a significant skill, writing is one of the four main skills which should be acquired in learning English as a foreign language. Not only is deemed as a channel of communication in which students welcome the chance of expounding their views and thoughts (Catts \& Kamhi, 2005; Graham, MacArthur \& Fitzgerald, 2007), it is in fact a precondition of learning other language skills (Al-Shourafa, 2012). Thus, it is construed as a means of learning; that is to say, one attains greater understanding of the topic in another way by dint of writing about a topic (Nathan \& Abernathy, 2012).

Nystrand (1989) maintains that writing is a social collaborative process interacting between the minds of the writer and reader (cited in Nathan \& Abernathy, 2012). By learning to write, students learn new ways of making sense of what they have acquired (Catts \& Kamhi, 2005; Feifer \& De Fina, 2002). Writing gives learners the impression of getting better and makes language learning more beneficial (Al-Shourafa, 2012).

Social constructionists consider writing as a social act which occurs in a particular context and for particular addresses (De Larios \& Murphy, 2001). Archibald (2001, p. 154) defines writing as "a skill that needs knowledge and proficiency in many areas. It is a multidimensional skill. It is a complex skill that results from the interaction of the writer's knowledge, experience, skills and the cognitive demands of the task".

Possessing the ability of writing well can exert a pronounced effect on our lives despite the fact that in the general education, research has indicated the intricacy of writing for students (Catts \& Kamhi, 2005; Harris, Graham, \& Mason, 2003; Hosseini, Taghizadeh, Zainol Abedin, \& Naseri, 2013).

In 2000, Suleiman made an assertion regarding to the significance of writing in learning, "Writing is a central element of language, any reading and language arts program must consider the multidimensional nature of writing in instructional practices, assessment procedures, and language developments" (p. 155). Good writing skills may raise students' possibilities for success (Alexander, 2008). Concerning the importance of writing in learning, Suleiman (2000) also emphasizes that writing is regarded as an indispensable feature of language.

\subsection{Goal-Setting}

According to Elliot and Murayama (2008) "a goal is conceptualized as an aim that one is committed to that serves as a guide for future behavior" (p. 614). Goals are considered as central constituent of motivation and learning (Bandura, 1988; Schunk, 2003). Based on goal-setting theory, we can expect high level of the expectancy, instrumentality, and valence of outcomes in case of having challenging (high), specific, and achievable goals (e.g., Fried \& Slowik, 2004; Locke \& Latham, 1990, 2002). In a similar vein, Pintrich and Schunk (1996) stated that concrete, difficult, and proximal goals were more likely to enhance students' motivation and persistence (cited in Bipp, Steinmayr, \& Spinath, 2012)

Goal-setting has to do with evaluating one's current performance to some chosen standards (Bandura, 1977). When students are provided with the opportunity of picking a goal, they are tend to become motivated and enjoy a sense of self-efficacy heading for achieving it.

The value of goal-setting to students lies in the fact that it is of utmost help for concentrating their attention, coordinating their efforts, showing more persistence, and designing new strategies (Covington, 2000; Elliot \& 
Students' educational level and their goal choices, self-efficacy, motivation, and writing performance

Dweck, 2005; Linnenbrink \& Pintrich, 2002; Locke \& Latham, 1990, 2002; Midgley, Kaplan, \& Middleton, 2001). Goals are rather short-term or long-term, easy or difficult for students to attain (Pintrich \& Schunk, 1996, cited in Bipp, Steinmayr, \& Spinath, 2012).

\subsection{Significance of the Study}

All things considered, the findings of this study can be fruitful and noteworthy given that many educators and researchers still overlook the worth of developmental pattern of university students; that is, their educational level on their success in educational contexts. In view of the fact that Iranian EFL learners may undergo a change of attitude in transition from BA level to MA level, their change of attitude can bring about the change in their efficacy beliefs, level of motivation, setting of goals, and writing performance. In addition, paucity of research in this realm in general and particularly in the context of Iran impelled us to conduct such a study which can throw more light on the potential importance of addressing university students' educational level and its effect on their success. With that in mind, the present study was designed to contribute to the effect of educational level on motivation, self-efficacy, goal-setting, and writing literatures because research has not yet examined the joint operation of these processes during Iranian EFL learners' developmental pattern/trend. Therefore, this study seeks to answer the following question:

$>\quad$ Does learners' educational level play any significant role in their self-efficacy, motivation, writing performance, and goal choice?

\section{Method}

\subsection{Participants}

A total of 93 Iranian EFL students (38 male and 55 female students) from Ferdowsi, Khayyam, and Imam Reza universities of Mashhad took part in this study. Participants' age ranged from 20 to 30 years. Participants' majors were Teaching English as a Foreign Language, English Literature, and English Translation. The ones chosen from Mashhad Universities were all undergraduate and graduate $(\mathrm{BA}=55$ and $\mathrm{MA}=38)$ students.

\subsection{Instrumentation}

Three questionnaires were utilized in the present study, namely, General Self-efficacy Scale, English Self-efficacy Scale, and Motivation Scale.

$>\quad$ Learners' General self-efficacy was assessed by 17 items from Sherer et al. (1982) on a five-point scale. In the current study, Cronbach's alpha for this scale was 0.89 .

$>\quad$ Students' English self-efficacy was measured through 10 items from Rahemi (2007) on a five-point scale. The total reliability of the scale in the current study, estimated via Cronbach's alpha, was 0.83 .

$>\quad$ To measure students' motivation, Language Learning Orientations Scale (LLOS) developed and validated by Noels, Pelletier, Clément, and Vallerand (2000) was used. It comprises 21 seven point Likert-scale in three sections measuring three subcomponents of intrinsic, extrinsic motivation, and amotivation. Cronbach's alpha for amotivation, extrinsic and intrinsic motivation were found to be respectively $0.81,0.85$, and 0.86 . It is worthy to note that the Persian version of the instrument, which was translated into Persian and validated by Khodadady and Khajavy (2013), was utilized in this study.

\subsection{Procedure}

Researchers came to a decision to assess learners' choice of goal through essay writing examination. The 
precondition of passing the writing course was specified for the students to take part and to be assessed with essay examination. The students were provided with three goal choices (A, B and C) and two possible writing topics a week before the exam day. The students had the opportunity of selecting one of the goals and getting themselves ready for the examination. Goal A was as a six-paragraph essay combined with six references. Goal $\mathrm{B}$ was designed as a five-paragraph essay with five references, and goal $\mathrm{C}$ was a four-paragraph essay coupled with four references.

As the participants needed to do longer and more challenging compositions with more research and preparation effort for each goal, the goals were resource-based. The goal-setting was proximal, time limited, and specific since the preparation time for the exam was limited and the requirements for the task were offered in depth.

It is of note that the participants were supposed to get one extra score and ten presents for taking part in this study. Moreover, the candidates were clearly told that their goal choices and quality of their writing directly related to their grades. A week later and before essay examination, the participants were supposed to fill out the questionnaires then the researchers selected one of the topics to be written about in the same session. The students' essays were scored by two raters based on the scale adopted by Engelhard, Gordon, and Gabrielson (1992). Furthermore, the inter-rater reliability for the scores was found to be .86 .

\section{Results}

To explore the possible difference between EFL learners' educational level in terms of English and General self-efficacy, subscales of motivation, goal choice, and writing performance, multivariate analysis of variance (MANOVA) and Chi-square were employed. Chi-square was used to investigate the possible difference between EFL learners' educational level in terms of goal choice. Table 1 presents the results of the Chi-square run to check the existence of any significant differences between the educational levels of Iranian EFL learners in the case of their choice of goals.

\section{Table 1}

Chi-square: Educational Level In Terms of Goal Choices

\begin{tabular}{lcrrrrr}
\hline Goal choice & $\begin{array}{c}\text { Educational } \\
\text { level }\end{array}$ & Observed N & Expected N & DF & $\chi^{2}$ & Sig. level \\
\multirow{2}{*}{$\mathrm{A}$} & BA & 12 & 24.2 & 2 & 30.976 & .000 \\
\hline \multirow{2}{*}{ B } & MA & 29 & 16.8 & 9.5 & & \\
\hline \multirow{2}{*}{ C } & BA & 10 & 6.5 & & \\
& MA & 33 & 21.3 & & \\
\hline
\end{tabular}

Analyzing the results of the Chi-square $\left(\chi^{2}=30.976, p<.001\right)$ revealed that there existed significant difference between learners' educational level and their choices of goals. According to Table 1, MA students preferred goal ' $A$ ' $(\mathrm{N}=29)$ more than is expected $(\mathrm{N}=16.8)$ which means that they saw themselves as able to pursue and attain high (hard) goal. By contrast, BA students opted for the same goal $(\mathrm{N}=12)$ much less than was expected $(\mathrm{N}=24.2)$ which carries this implication that they were less likely to set the challenging goal. As indicated for goal ' $\mathrm{C}$ ', BA students tended to choose this goal $(\mathrm{N}=33)$ more than was expected $(\mathrm{N}=21.3)$. It implies that BA EFL learners avoided setting the demanding goal for themselves; however, they were willing to pick the easy goal. In contrast, MA learners showed less tendency $(\mathrm{N}=3)$ toward the same goal as expected $(\mathrm{N}=$ 14.7). As we can see for goal ' $B$ ', there was less difference between the observed and expected numbers of BA $(\mathrm{N}=10 / 9.5)$ and MA students $(\mathrm{N}=6 / 6.5)$ who chose this goal.

Overall, as it can be seen in Table 1, MA students exhibited strong tendency to pursue the harder goal and 
seemed satisfied with adopting it, as compared with BA students who showed great willingness toward being assigned the easier goal. Put differently, MA students committed themselves to adherence and resistance to the challenging goal as opposed to BA learners who did not put themselves to trouble of attaining hard goal. To conclude, the most favored goal among MA students was ' $\mathrm{A}$ ', and goal ' $\mathrm{C}$ ' found to be the most prevailing goal among BA learners. Additionally, goal ' $C$ ' was considered as the least favored option among MAs, and goal ' $\mathrm{B}$ ' ranked the last one among BAs.

As mentioned before, MANOVA was run to analyze the data. The descriptive statistics for the dependent variables in terms of educational level is provided in Table 2.

Table 2

Descriptive Statistics: Level in English and General Self-Efficacy, and Subscales of Motivation

\begin{tabular}{llccc}
\hline & Educational Level & Mean & SD & $n$ \\
\hline English self-efficacy & BA & 39.9091 & 6.29012 & 55 \\
& MA & 42.9211 & 5.58657 & 38 \\
& Total & 41.1398 & 6.16369 & 93 \\
\hline General self-efficacy & BA & 60.9455 & 9.39941 & 55 \\
& MA & 65.1316 & 11.17954 & 38 \\
& Total & 62.6559 & 10.31514 & 93 \\
\hline Extrinsic motivation & BA & 37.2727 & 8.12735 & 55 \\
& MA & 40.7368 & 7.84197 & 38 \\
& Total & 38.6882 & 8.15072 & 93 \\
\hline Intrinsic motivation & BA & 46.8182 & 11.47798 & 55 \\
& MA & 48.3947 & 8.72876 & 38 \\
& Total & 47.4624 & 10.42005 & 93 \\
\hline Amotivation & BA & 4.8182 & 2.90013 & 55 \\
& MA & 4.0263 & 2.61479 & 38 \\
& Total & 4.4946 & 2.79994 & 93 \\
\hline Writing & BA & 17.3955 & 1.77475 & 5 \\
& MA & 18.4013 & 1.50510 & 55 \\
\hline
\end{tabular}

A brief inspection of Table 2 displays that the mean scores for MA participants in General and English self-efficacy, intrinsic and extrinsic motivation, and writing were more than BAs. In General self-efficacy, MAs were more successful $\left(\mathrm{X}^{\prime}=65.13\right)$ than BAs $\left(\mathrm{X}^{\prime}=60.94\right)$ which indicates MAs' better performance in General self-efficacy. In this vein, MA learners showed better mean score in English self-efficacy $\left(X^{\prime}=42.92\right)$ than BAs $\left(X^{\prime}=39.90\right)$. To put it differently, MAs felt capable and confident about their capabilities. So, their self-efficacy was higher than that of BAs'; they felt more efficacious than BAs.

In the same fashion, in intrinsic and extrinsic motivation, the mean score for MAs was higher than BAs. It's worth mentioning that MAs' intrinsic motivation $\left(\mathrm{X}^{\prime}=48.39\right)$ was higher than their extrinsic motivation $\left(\mathrm{X}^{\prime}=\right.$ 40.73).This would mean that MAs freely chose the activity because they viewed the activity as interesting and fun to do. In comparison, although the mean scores of BA students in intrinsic and extrinsic motivation were less than MAs, BAs indicated to be more extrinsically motivated as opposed to MAs. That is, they liked to undertake the activity merely to attain rewards. In writing performance, MA learners also $\left(X^{\prime}=18.40\right)$ surpassed BAs $\left(X^{\prime}=\right.$ 17.39) in higher scores which indicates MAs' better performance in writing module. In other words, MA students enjoyed higher score bands in writing and they were considered as better writers than BAs. At last, in amotivation, BAs' mean score $\left(X^{\prime}=4.81\right)$ was slightly higher than MAs' $\left(X^{\prime}=4.02\right)$. This would mean that BAs sometimes found themselves more amotivated than MAs; sometimes they saw no reason for doing an activity more than MAs did. Table 3 presents the result of Multivariate Tests.

It can be inferred from the table that we have a $p$ value of .024 which is statistically significant. Thus, we can conclude that educational level did have a significant effect on students' writing performance, subscales of motivation, English and General self-efficacy. That is, there was a statistically significant difference between 
Hosseini Fatemi, A. \& Vahidnia, F.

students' educational level and their writing performance, extrinsic and intrinsic motivation, amotivation, English and General self-efficacy ( $\mathrm{F}=2.582, p<.05$; Wilk's $\lambda=0.847$ ). Table 4 depicts the results of five separate univariate ANOVAs.

Table 3

Multivariate Tests for Educational Level

\begin{tabular}{llllll}
\hline & Effect & Value & F & Sig. & Partial eta $^{2}$ \\
\hline \multirow{6}{*}{ Level } & Pillai's Trace & .153 & $.582^{\mathrm{a}}$ & .024 & .153 \\
& Wilks' Lambda & .847 & $2.582^{\mathrm{a}}$ & .024 & .153 \\
& Hotelling's Trace & .180 & $2.582^{\mathrm{a}}$ & .024 & .153 \\
& Roy's Largest Root & .180 & $2.582^{\mathrm{a}}$ & .024 & .153 \\
\hline
\end{tabular}

Note. ${ }^{\text {a }}$ Exact statistic

Table 4

Educational Level by DVs

\begin{tabular}{clrrrrr}
\hline Source & Dependent variable & $\begin{array}{c}\text { Type III sum } \\
\text { of squares }\end{array}$ & Df & Mean square & F & Sig. \\
\hline \multirow{5}{*}{ Educational } & General self-efficacy & 393.811 & 1 & 393.811 & 3.814 & .054 \\
level & English self-efficacy & 203.874 & 1 & 203.874 & 5.637 & .020 \\
& Intrinsic & 55.858 & 1 & 55.858 & 0.512 & .476 \\
& Extrinsic & 269.679 & 1 & 269.679 & 4.201 & .043 \\
& Amotivation & 14.092 & 1 & 14.092 & 1.813 & .181 \\
& Writing & 22.737 & 1 & 22.737 & 8.149 & .005 \\
\hline
\end{tabular}

Based on Table 4, educational level had a significant effect on the results of extrinsic motivation ( $p=.043$ ), English self-efficacy $(\mathrm{p}=.020)$, and writing performance $(p=.005)$. Therefore, the results indicated that there was a significant difference between educational level in English self-efficacy $(\mathrm{F}=5.637, p<.05)$, extrinsic motivation $(\mathrm{F}=4.201, p<.05)$, and writing performance $(\mathrm{F}=8.149, p<.05)$. However, the results demonstrated that educational level did not have a significant effect on the results of intrinsic motivation, General self-efficacy, and amotivation. The findings just revealed that educational level appeared to be an important variable which affected students' English self-efficacy, extrinsic motivation, and writing performance.

In closing, educational level differences revealed that MA students reported higher English self-efficacy, higher extrinsic motivation, and higher grades in writing module than BA students.

\section{Discussion}

The obtained results regarding self-efficacy are in consistency with Bandura's claim (1986) that self-efficacy progresses in stages when an individual moves on through life's various phases. In the same vein, higher level of MAs' self-efficacy was obvious in the current research. Our findings also manifested what Bandura (1986) has claimed; that is, the improvement in actual cognitive and behavioral skills is directly accompanied with the development of higher self-efficacy and; thus, it can be inferred that as long as these skills develop, so will self-efficacy.

Contrary to our expectation, MAs got higher scores than BAs in intrinsic and extrinsic motivation. By continuing the investigation of educational level differences, the presented result provided a significant extension to the prior inquiry regarding the development of motivational beliefs (Stipek, 1993). The foregoing finding contradicts earlier work by Harter (1981, cited in Carreira, 2006) who claimed that students' intrinsic motivation for learning lessened generally with age. Counter to our findings, earlier research concerning grade differences implies that students are likely to have lower motivation at higher levels of schooling (Lepper et al., 2005, cited in Yeung, Lau, \& Nie, 2011; Murphy \& Alexander, 2000; Watt, 2008; Yeung \& McInerney, 2005). They have claimed that as the pupils grow up, their adaptive motivation tends to lessen and their motivation gradually 
weakens over time, especially during adolescence.

The fact that MA Iranian EFL learners exhibited higher level of motivation than BAs can be related to two factors, namely social and environmental factors which influence an individual's motivation. The effect of social factors (e.g., students' attitude toward learning) enables an individual to apparently improve his motivation at higher levels of education. Gardner (1985) stated that "students' attitudes toward the specific language group are bound to influence how successful they will be in incorporating aspects of that language" (p. 6). His assertion would mean that social context of motivation such as language attitude is of utmost importance in enhancing or reducing motivation so students' attitude may cast light on this finding. MA Iranian EFL learners might have more positive attitude toward learning English than BA students, which resulted in their higher level of motivation, that is, a change of attitude might occur in transition from BA level to MA.

The second reason for MAs greater level of motivation can be explained through environmental factors (e.g., class climate, teacher, care and support). Noels (2001) stated that "the more students perceived their teachers as controlling and as failing to provide instructive feedback, the less they were intrinsically motivated" (cited in Dornyei, 2005, p. 77). Thus, the perception of autonomy, support, and informative feedback from teachers can improve pupils' intrinsic motivation. In a similar vein, current studies have revealed significant relationships between classroom environments and students' motivation in learning. As a case in point, Lee et al. (2009) attested that there was a positive association between students' intrinsic motivation and a positive classroom environment with great teacher support. While research has indicated that teachers' behaviors had significant effect on students' motivation (den Brok et al., 2005), evidence has also revealed that a change in the physical environment could bring about a change in students' learning motivation (McEwan et al., 2010). Here the salient role of teachers in students' motivation comes into scene. BA students usually study in teacher-centered classrooms in which everything is under the control of teachers in the context of Iran. In such controlling teacher classrooms, they are not considered as active learners; teacher knows everything and dominates students' behaviors.

On the other hand, MA students have more opportunities to solve challenges and to take on the responsibility of their own learning; they are expected to be cultivated in student-centered classrooms in which they enjoy more autonomy. Deci and Ryan argue that "when the educational environment provides optimal challenges, rich sources of stimulation, and a context of autonomy, this motivational wellspring in learning is likely to flourish" (1985, p. 245). Hence, it seems patent that MA EFL learners who felt autonomous in their behavior, exhibited higher level of motivation as compared with BAs.

Concerning amotivation, BAs sometimes found themselves more amotivated than MAs; sometimes they saw no reason for doing an activity more than MAs did. The reason behind this finding can be clarified in the light of autonomous learners. Since amotivated students find no relation between their actions and succeeding consequences, they tend to develop a passive attitude which is not a characteristic related to autonomous learner (Littlewood, 1996). Therefore, MA students were less amotivated in comparison to BAs because they found themselves more autonomous due to being educated in student-centered classrooms.

In writing performance, MA learners also outdid BAs; they were considered as better writers than BAs. To the best of the present researchers' knowledge, the role of educational level differences in EFL learners' writing achievement in the global context in general and in the context of Iran, seems rather unexplored. Accordingly, the present researchers cannot draw a comparison between the roles of educational level differences in EFL learners' writing performance. The fact that MA Iranian EFL learners taking part in this study represented higher writing achievement may be interpreted in the light of the assumption that MA Iranian learners are expected to be trained in student-centered classrooms, the basic requirements of which is a relaxed and anxiety-free environment. Larsen-Freeman (2000) argued that student-centered classrooms the requirements of which are a relaxed and anxiety-free environment enable learners to remove anxiety and stress. Furthermore, MacIntyre and his colleagues' research (MacIntyre, 1999, 2002; MacIntyre \& Gardner, 1991a, 1991b, 1994) provided additional 
support for the negative relationship between language anxiety and performance in the second language. Hence, due to being studied in student-centered environment, MA students might feel relaxed and experienced lower level of anxiety which resulted in their better performance in writing.

Another finding revealed by this research was that there existed significant difference between learners' educational level and their choice of goals. In contrast to MA students who preferred high (hard) goals, BA students opted for the easy goal. As far as the researchers know, the role of educational level differences in EFL learners' choice of goals in the global context in general and particularly in the context of Iran, seems rather untouched. So the researcher cannot draw a comparison between the roles of educational level differences on EFL learners' choice of goals.

To account for this result, we can turn to the concept of self-efficacy. Pajares (2002a) stated that self-efficacy affects the choices one makes, one's persistence toward the goal, and the effort one invests into the task. To put it differently, those students who have high self-efficacy will pursue higher goals, show greater persistence, and exert remarkable effort (VanZile Tamsen \& Livingstone, 1999). In contrast, those who have low self-efficacy will be more likely to give up easily in the face of finding a difficult task (Zimmerman, 1995, 2000). Hence, MAs' stronger self-efficacy resulted in considering themselves more competent about their capabilities and being sure about undertaking the challenging goal as compared to the BAs. In other words, participants of this study matched their choices with the self-efficacy beliefs attached to them.

This finding can also be explained with regard to the students' intrinsic motivation. Students who are intrinsically motivated tend to persist longer to attain their goals (Pokay \& Blumenfeld, 1990; Vansteenkiste et al., 2006). In addition, "Perceived competence and autonomy, in turn, result in a significantly higher level of L2 intrinsic motivation" (Dornyei, 2005, p. 71). Consequently, MA learners who exhibited higher self-efficacy, showed higher intrinsic motivation and as a result they preferred the challenging goal. It would mean that the reciprocal relationship between their self-efficacy and intrinsic motivation affected their choice of goals.

\section{Conclusion}

As already mentioned, in this study we did our best shot to study the effect of Iranian EFL learners' educational level on their goal choices, efficacy beliefs, motivation, and their writing scores. Overall, the results of this study revealed that MA learners exhibited higher level of English and General self-efficacy and motivation. In addition, MAs surpassed BAs in writing scores and selected the most challenging goal as compared to BAs who preferred to pick the easy goal.

There were a number of limitations in this paper which can be addressed in future studies. First, interpreting the cross-sectional data of this research with respect to a developmental trend should be treated with caution. To arrive at deep understanding of the developmental patterns of students' motivation, self-efficacy, and goal-setting, a longitudinal study should be carried out. Second, students' motivation and efficacy beliefs may fluctuate in specific curriculum fields and within different disciplines. Accordingly, further research can be conducted to remedy this vacuum and examine students' motivation, self-efficacy, and goal setting in curriculum fields except the English domain presented here. Further, the patterns reported in the current research paper with the presented sample should not be generalized within different disciplines. Ultimately, this paper narrowed its focus to motivational studies, an area which will surely form the foundation of pedagogical purposes and educational contexts in Iran. Other factors such as cognitive and linguistic development and sociocultural factors ought to be scrutinized in the future.

This study represents a first step in conceptualizing differences between BA and MA EFL university learners in writing module and goal-setting, motivation, and self-efficacy theories. We are hopeful that this study and subsequent studies will provide information which will be of use in implementing and accelerating educational reform. Such research would be a valuable addendum to the literature on educational level and related variables. Notwithstanding its limitations, this study contributes towards uncovering and understanding the developmental 
pattern of Iranian EFL university students' efficacy beliefs and level of motivation. Beyond a shadow of doubt, it also helps to illuminate the outstanding influence of students' educational level in their writing module and their choice of academic goals. More to the point, as motivation, self-efficacy, and setting goals have utmost significant effects on learning, educators and curriculum designers are required to take ways into account to boost and maintain these constructs.

\section{References:}

Al-Shourafa, A. (2012). The effect of motivation on Jordanian $10^{\text {th }}$ grades students' writing skill in English. European Scientific Journal, 8(22), 235-247.

Archibald, A. (2001). Targeting L2 writing proficiencies: Instructions and areas of change in students writing over time. International Journal of English studies, 1(2), 153-160.

Bandura, A. (1977). Social learning theory. Englewood Cliffs, NJ: Prentice-Hall.

Bandura, A. (1986). Social foundations of thought and action: A social cognitive theory. Englewood Cliffs, NJ: Prentice-Hall.

Bandura, A. (1988). Self-regulation of motivation and action through goal systems. In V. Hamilton, G. H. Bower, $\&$ N. H. Frijda (Eds.), Cognitive perspectives on emotion and motivation (pp. 37-61). Dordrecht, The Netherlands: Kluwer Academic Publishers. http://dx.doi.org/10.1007/978-94-009-2792-6_2

Bandura, A. (2001). Social cognitive theory: An agentic perspective. Annual Review of Psychology, 52, 1-26. http://dx.doi.org/10.1146/annurev.psych.52.1.1

Bandura, A., \& Locke, E. A. (2003). Negative self-efficacy and goal effect revisited. Journal of Applied Psychology, 88, 87-99. http://dx.doi.org/10.1037/0021-9010.88.1.87

Bipp, T., Steinmayr, R., \& Spinath, B. (2012). A functional look at goal orientations: Their role for self-estimates of intelligence and performance. Learning and Individual Differences, 22, 280-289. http://dx.doi.org/10.1016/j.lindif.2012.01.009

Broussard, S. C., \& Garrison, M. E. B. (2004). The relationship between classroom motivation and academic achievement in elementary school-aged children. Family and Consumer Sciences Research Journal, 33(2), 106-120. http://dx.doi.org/10.1177/1077727X04269573

Carreira, J. M. (2006). Motivation for learning English as a foreign language in Japanese elementary schools. JALT Journal, 28(2), 135-158.

Catts, H. W., \& Kamhi, A. G. (2005). Language and reading disabilities (2nd ed.). Boston: Allyn and Bacon.

Covington, M. V. (2000). Goal theory, motivations, and school achievement: An integrative review. Annual Reviews of Psychology, 51, 171-200. http://dx.doi.org/10.1146/annurev.psych.51.1.171

De Larios , J. R., \& Murphy, L. (2001). Some steps towards a socio cognitive. Interpretation of second language composition process. International Journal of English studies, 1(2), 25-46.

Deci, E. L., \& Ryan, R. M. (1985). Intrinsic motivation and self-determination in human behaviour. New York: Plenum. http://dx.doi.org/10.1007/978-1-4899-2271-7

den Brok, P., Levy, J., Brekelmans, M., \& Wubbels, T. (2005). The effect of teacher interpersonal behavior on students' subject-specific motivation. Journal of Classroom Interaction, 40(2), 20-33.

Dornyei, Z. (2005). The psychology of the language learner: Individual differences in second language acquisition. Mahwah, NJ: Lawrence Erlbaum Associates, Inc.

Dornyei, Z., \& Ottó, I. (1998). Motivation in action: A process model of L2 motivation. Working papers in Applied Linguistics, 4, 43-69.

Elliot, A. J., \& Dweck, C. S. (2005). Competence and motivation. Competence as the core of achievement motivation. In A. J. Elliot, \& C. S. Dweck (Eds.), Handbook of competence and motivation (pp. 3-12). New York: Guildford Press.

Elliot, A. J., \& Murayama, K. (2008). On the measurement of achievement goals: Critique, illustration, and application. Journal of Educational Psychology, 100, 613-628. http://dx.doi.org/10.1037/0022-0663.100.3.613

Engelhard, G., Gordon, B., \& Gabrielson, S. (1992). The influences of mode of discourse, experiential demand, 
and gender on the quality of student writing. Research in the Teaching of English, 26, 315-336.

Feifer, S. G., \& De Fina, P. A. (2002). The neuropsychology of written language disorders: Diagnosis and intervention. Middletown, MD: School Neuropsych Press, LLC.

Fried, Y., \& Slowik, L. H. (2004). Enriching goal-setting theory with time: An integrated approach. Academy of Management Review, 29(3), 404-422.

Gardner, R. C. (1985). Social psychology and second language learning: The role of attitudes and motivation. London: Edward Arnold.

Graham, S., MacArthur, C. A., \& Fitzgerald, J. (2007). Best practices in writing instruction. In S. Graham, C. A. MacArthur, \& J. Fitzgerald (Eds.), Best practices in writing instruction (pp. 1-9). New York, NY: Guilford Press.

Guthrie, J. T., Wigfield, A., \& VonSecker, C. (2000). Effects of integrated instruction on motivation and strategy use in reading. Journal of Educational Psychology, 92(2), 331-341. http://dx.doi.org/10.1037/0022-0663.92.2.331

Harris, K. R., Graham, S., \& Mason, L. H. (2003). Self-regulated strategy development in the classroom: Part of a balanced approach to writing instruction for students with disabilities. Focus on Exceptional Children, 35(7), 1-16.

Hosseini, M., Taghizadeh, M. E., Zainol Abedin, M. J., \& Naseri, E. (2013). In the importance of EFL learners' writing skill: Is there any relation between writing skill and content score of English essay test? International Letters of Social and Humanistic Sciences, 6, 1-12.

Khodadady, E., \& Khajavy, G. H. (2013). Exploring the role of anxiety and motivation in foreign language achievement: A structural equation modeling approach. Porta Linguarum, 20, 269-286.

Larsen-Freeman, D. (2000). Techniques and principles in language teaching ( $2^{\text {nd }}$ ed.). Oxford: Oxford University Press.

Lee, J. C. K., Yin, H., \& Zhang, Z. (2009). Exploring the influence of the classroom environment on students' motivation and self-regulated learning in Hong Kong. Asia-Pacific Education Researcher, 18, 219-232. http://dx.doi.org/10.3860/taper.v18i2.1324

Linnenbrink, E. A., \& Pintrich, P. R. (2002). Achievement goal theory and affect: An asymmetrical bidirectional model. Educational Psychologist, 37, 69-78. http://dx.doi.org/10.1207/S15326985EP3702_2

Littlewood, W. (1996). Autonomy: An anatomy and a framework. System, 24, 427-435. http://dx.doi.org/10.1016/S0346-251X(96)00039-5

Locke, E. A., \& Latham, G. P. (1990). A theory of goal setting and task performance. Englewood Cliffs, NJ: Prentice-Hall.

Locke, E. A., \& Latham, G. P. (2002). Building a practically useful theory of goal setting and task motivation: A 35-year odyssey. American Psychologist, 57, 705-717. http://dx.doi.org/10.1037/0003-066X.57.9.705

Locke, E. A., Frederick, E., Lee, C., \& Bobko, P. (1984). Effect of self-efficacy, goals, and task strategies on task performance. Journal of Applied Psychology, 69, 241-251. http://dx.doi.org/10.1037/0021-9010.69.2.241

Locke, E. A., Motowidlo, S. J., \& Bobko, P. (1986). Using self-efficacy theory to resolve the conflict between goal-setting theory and expectancy theory in organizational behavior and industrial/ organizational psychology. Journal of Social and Clinical Psychology, 4, 328-338. http://dx.doi.org/10.1521/jscp.1986.4.3.328

MacIntyre, P. D. (1999). Language anxiety: A review of the research for language teachers. In D. J. Young (Ed.), Affect in foreign language and second language learning (pp. 24-45). Boston: McGraw-Hill.

MacIntyre, P. D. (2002). Motivation, anxiety and emotion in second language acquisition. In P. Robinson (Ed.), Individual differences in second language acquisition (pp. 45-68). Amsterdam: John Benjamins.

MacIntyre, P. D., \& Gardner, R. C. (1991a). Language anxiety: Its relation to other anxieties and to processing in native and second languages. Language learning, 41, 513-534. http://dx.doi.org/10.1111/j.1467-1770.1991.tb00691.x

MacIntyre, P. D., \& Gardner, R. C. (1991b). Methods and results in the study of anxiety in language learning: A review of the literature. Language learning, 41, 85-117. 
Students' educational level and their goal choices, self-efficacy, motivation, and writing performance http://dx.doi.org/10.1111/j.1467-1770.1991.tb00677.x

MacIntyre, P. D., \& Gardner, R. C. (1994). The subtle effects of language anxiety on cognitive processing in the second language. Language learning, 44, 283-305. http://dx.doi.org/10.1111/j.1467-1770.1994.tb01103.x

McCarthy, P., Meier, S., \& Rinderer, R. (1985). Self-efficacy and writing: A different view of self-evaluation. College Composition and Communication, 36(4), 465-471. http://dx.doi.org/10.2307/357865

McEwan, S., Edgerton, E., \& McKechnie, J. (2010). Changing school environments and educational outcomes: A longitudinal approach. Psychology of Education Review, 34, 6-33.

Midgley, C., \& Edelin, K. C. (1998). Middle school reform and early adolescent wellbeing: The good news and the bad. Educational Psychologist, 33, 195-206. http://dx.doi.org/10.1207/s15326985ep3304_4

Midgley, C., Kaplan, A., \& Middleton, M. (2001). Performance-approach goals: Good for what, for whom, under what circumstances, and at what cost? Journal of Educational Psychology, 80, 514-23.

Murphy, P. K., \& Alexander, P. A. (2000). A motivated exploration of motivation terminology. Contemporary Educational Psychology, 25, 3-53. http://dx.doi.org/10.1006/ceps.1999.1019

Nathan, A. M., \& Abernathy, T. V. (2012). The impact of verbal skills on writing: A comparison of fifth-grade students with learning disabilities and students with typical development. The Researcher, 24(2), 96-112.

Noels, K. A., Pelletier, L. G., Clément, R., \& Vallerand, R. J. (2000). Why are you learning second language? Motivational orientations and self-determination theory. Language Learning, 50, 57-85. http://dx.doi.org/10.1111/0023-8333.00111

Pajares, F. (2002a).Overview of social cognitive theory and of self-efficacy. Retrieved March 11, 2010, from http://www.emory.edu/EDUCATION/mfp/eff.html

Pajares, F., \&. Schunk. D. H. (2001). Self-beliefs and school success: Self-efficacy, self-concept, and school achievement. In R. Riding \& S. Rayner (Eds.), Perception (pp. 239-266). London: Ablex Publishing.

Paris, S. G., \& Oka, E. R. (1986). Children's reading strategies, metacognition and motivation. Developmental Review, 6, 25-56. http://dx.doi.org/10.1016/0273-2297(86)90002-X

Pokay, P., \& Blumenfeld, P. C. (1990). Predicting achievement early and late in the semester: The role of motivation and use of learning strategies. Journal of Educational Psychology, 82, 41-50. http://dx.doi.org/10.1037/0022-0663.82.1.41

Rahemi, J. (2007). Self-efficacy in English and Iranian senior high school students majoring in humanities. Novitas-ROYAL, 1(2), 98-111.

Schunk, D. H. (2003). Self-efficacy for reading and writing: Influence of modeling, goal setting and self-evaluation. Reading and Writing Quarterly: Overcoming Learning Difficulties, 19(2), 159-172. http://dx.doi.org/10.1080/10573560308219

Schunk, D. H., \& Pajares, F. (2002). The development of academic self-efficacy. In A. Wigfield \& J. Eccles (Eds.), Development of achievement motivation (pp. 16-31). San Diego: Academic Press. http://dx.doi.org/10.1016/B978-012750053-9/50003-6

Schunk, D. H., \& Swartz, C. W. (1993). Goals and progress feedback: Effects on self-efficacy and writing achievement. Contemporary Educational Psychology, 18, 337-354. http://dx.doi.org/10.1006/ceps.1993.1024

Shell, D. F., Murphy, C. C., \& Bruning, R. H. (1989). Self-efficacy and outcome expectancy mechanisms in reading and writing achievement. Journal of Educational Psychology, 81, 91- 100. http://dx.doi.org/10.1037/0022-0663.81.1.91

Sherer, M., Maddux, J. E., Mercandante, B., Prentice-Dunn, S., Jacobs, B., \& Rogers, R. W. (1982). The self-efficacy scale: Construction and validation. Psychological Reports, 51, 663-671. http://dx.doi.org/10.2466/pr0.1982.51.2.663

Stipek, D. J. (1993). Motivation to learn: From theory to practice (2nd ed.). Needham Heights, MA: Allyn \& Bacon.

Suleiman, M. F. (2000). The process and product of writing: Implications for elementary school teachers. Presented at California Association for Bilingual Education Conference. 
Hosseini Fatemi, A. \& Vahidnia, F.

Vansteenkiste, M., Lens, W., \& Deci, E. L. (2006). Intrinsic versus extrinsic goal contents in self-determination theory: Another look at the quality of academic motivation. Educational Psychologist, 41(1), 19-31. http://dx.doi.org/10.1207/s15326985ep4101_4

VanZile-Tamsen, C., \& Livingston, J. A. (1999). The differential impact of motivation on the self-regulated strategy use of high-and low-achieving college students. Journal of College Student Development, 40, $54-60$.

Watt, H. M. G. (2008). A latent growth curve modeling approach using an accelerated longitudinal design: The ontogeny of boys' and girls' talent perceptions and intrinsic values through adolescence. Educational Research and Evaluation, 14, 287-304. http://dx.doi.org/10.1080/13803610802249316

Yeung, A. S., \& McInerney, D. M. (2005). Students' school motivation and aspiration over high school years. Educational Psychology, 25, 537-554. http://dx.doi.org/10.1080/01443410500046804

Yeung, A. S., Lau, S., \& Nie, Y. (2011). Primary and secondary students' motivation in learning English: Grade and gender differences. Contemporary Educational Psychology, 36, 246-256. http://dx.doi.org/10.1016/j.cedpsych.2011.03.001

Zimmerman, B. J. (1995). Self-efficacy and education development. In A. Bandura (Ed.), Self- efficacy in changing societies (pp. 202-231). New York: Cambridge University Press. http://dx.doi.org/10.1017/CBO9780511527692.009

Zimmerman, B. J. (2000). Self-efficacy: An essential motive to learn. Contemporary. Educational Psychology, 25, 82-91. http://dx.doi.org/10.1006/ceps.1999.1016 